\title{
KONSEP PROFESI DAN SIKAP PROFESIONAL KEGURUAN
}

\section{Nurhikmah}

\author{
Email: 191028120006@mhs.ulm.ac.id \\ Program Studi Pendidikan Ilmu Pengetahuan Sosial Fakultas Keguruan dan Ilmu \\ Pendidikan \\ Universitas Lambung Mangkurat \\ Banjarmasin
}

\begin{abstract}
Abstrak
Guru merupakan sosok yang begitu dihormati karena memiliki sumbangan yang cukup besar terhadap kcberhasilan pembelajaran di sekolah. Minat, bakat, kemampuan dan potensi peserta didik tidak akan berkembang secara optimal tanpa bantuan guru. Dalam kaitan ini guru perlu memperhatikan peserta didik secara individual. Tugas guru tidak hanya mengajar, namun juga mendidik, mengasuh, membimbing dan membentuk kepribadian anak didik guna menyiapkan dan mengemmbangkan sumber daya yang dimiliki masing-masing peserta didik.
\end{abstract}

\section{PENDAHULUAN}

Kata profesi dalam bahasa inggris dikenal dengan kata profession, dalam bahasa Belanda dikenal dengan kata professie yang diambil dari bahasa latin professio yang artinya pengakuan atau pernyataan. Menurut Jalal (2011) dalam Nurjan (2015), menjelaskan bahwa apa yang telah dinyatakan atau diakui disebut professus.

Menurut Nurjan (2015), ia menjelaskan bahawa dalam bidang pekerjaan, profesi berarti pengakuan atau pernyataan tentang pekerjaan atau bidang pengeabdian yang dipilih Orang yang menyatakan profesinya sebagai guru, sebenarnya ia menyatakan bahwa pekerjaan yang dipilihnya adalah sebagai pendidik.

Profesi dapat diartikan sebagai suatu pekerjaan atau jabatan yang menuntut keahlian, yang didapat melalui pendidikan dan latihan tertentu, menurut persyaratan khusus memiliki tanggung jawab dan kode etik tertentu. Pekerjaan yang bersifar profesional berbeda dengan pekerjaan lainnya karena suatu profesi memerlukan kemampuan dan keahlian khusus dalam 
melaksanakan profesinya. Profesi juga diartikan sebagai suatu jabatan atau pekerjaan tertentu yang mensyaratkan pengetahuan dan keterampilan khusus yang diperoleh dari pendidikan akademis yang intensif. (Susanto, 2020: 11)

Menurut Susanto (2020: 12), secara umum syarat pekerjaan dapat digolongkan menjadi suatu profesi sebagai berikut:

1) Memiliki spesialisasi ilmu; setiap profesi dibangun berdasarkan kekhususan keilmuan, sehingga orang yang masuk dalam suatu bidang profesi haruslah orang yang memiliki latar belakang keilmuan yang sesuai. Hal ini menjelaskan bahwa tidak sembarang orang dapat bekerja di suatu bidang profesi jika tidak memiliki latar belakang keilmuan yang relevan. 2) Memiliki kode etik dalam menjalankan profesi; kode etik merupakan pedoman etik/pedoman moral bagi anggota profesi dalam menjalankan tugasnya. Kode etik profesi diperlukan untuk menjaga martabat dan menjadi pedoman bagi insan profesi dalam menjalankan profesinya. 3) Memiliki organisasi profesi; organisasi merupakan wadah perjuangan dan perkumpulan insan profesi. Organisasi profesi juga berfungsi sebagai wadah untuk pengembangan profesi melalui sharing inovasi dan komunikasi suatu profesi. Melalui organisasi ini insan profesi akan memiliki kesepakatan yang sama dalam menjalankan profesinya dan memiliki kemampuan untuk merespon berbagai kebijakan dan tantangan terkait profesi. Organisasi profesi dapat menjadi simbol kuatnya suatu profesi di tengah masyarakat. 4) Diakui masyarakat; suatu profesi harus mendapat pengakuan masyarakat. Pengakuan ini diperoleh jika profesi tersebut telah terbukti memiliki peran sesuai bidangnya. Pengakuan masyarakat merupakan bentuk legimitasi terhadap keberadaan dan peran suatu profesi. 5) Sebagai panggilan hidup; profesi merupakan karir sepanjang hayat, dengan demikian profesi akan mendarah daging bagi orang yang menjalankannya. Bekerja di bidang profesi sangat berbeda dengan bekerja di bidang lain, bekerja di bidang profesi mengharuskan seseorang untuk mengabdikan diri secara penuh dan terus mendalami keilmuan bidang profesi tersebut, sehingga semakin lama seseorang berkecimpung dalam suatu bidang profesi maka akan semakin ahli dalam bidang tersebut. 6) Dilengkapi kecakapan diagnostik; sebagai bidang pekerjaan yang memerlukan pengambilan keputusan otonom dari insan profesi, maka orang yang bekerja di bidang profesi diharuskan memiliki kemampuan diagnostik. Kemampuan diagnostik adalah kemampuan memperkirakan penyebab dan atau akibat berdasarkan gejala 
atau ciri-ciri tertentu, menganalisis, serta kemampuan untuk menentukan tindakan yang tepat untuk menangani atau menyelesaikan permasalahan. 7) Mempunyai klien yang jelas; karena profesi merupakan pekerjaan di bidang jasa, maka setiap profesi pasti memiliki klien yang jelas. Dokter memiliki klien pasien, pengacara memiliki klien orang yang berperkara hukum, guru memiliki klien murid. Kejelasan klien ini yang menunjukkan bahwa bidang profesi adalah pekerjaan yang sangat spesifik dan berbeda antara satu profesi dengan profesi lainnya, sehingga seseorang tidak dapat beralih profesi tanpa latar belakang pendidikan dan keahlian yang relevan.

Profesionalisme guru perlu didukung oleh suatu kode etik guru yang berfungsi sebagai norma hukum dan sekaligus sebagai norma kemasyarakatan. Kelembagaan profesi guru (seperti PGRI) sangat diperlukan untuk menghindari terkotak-kotaknya guru karena alasan struktur birokratisasi atau kepentingan politik tertentu. Profesionalisme guru harus didukung oleh kompetensi yang standar yang harus dikuasai oleh para guru profesional. Kompetensi tersebut adalah pemilikan kemampuan atau keahlian yang bersifat khusus, tingkat pendidikan minimal, dan sertifikasi keahlian haruslah dipandang perlu sebagai prasarat untuk menjadi guru profesional.

Seiring kemajuan teknologi sekarang yagn makin pesat guru tidak lagi hanya bertindak sebagai penyaji informasi, tetapi juga harus mampu bertindak sebagai fasilitator, motivator, dan pembimbing bagi peserta didik untuk mencari dan mengolah informasi.

\section{PERAN GURU SEBAGAI SEBUAH PROFESI}

2) Mengapa guru dapat digolongkan/diklasifikasikan sebagai sebuah profesi?

3) Bagaimana peran, hak, dan kewajiban guru menurut Undang-undang No. 14 tahun 2005 tentang guru dan dosen, serta menurut para ahli?

Menurut Susanto (2020: 14), ia menjelaskan bahawa guru merupakan suatu profesi, yang berarti suatu jabatan yang memerlukan keahlian khusus sebagai guru dan tidak dapat dilakukan oleh sembarang orang diluar bidang pendidikan. Walaupun pada kenyataannya 
masih terdapat guru yang tidak memiliki latar belakang pendidikan bidang keguruan. Seorang guru berkaitan dengan aktivitas profesinya duharuskan mengetahui dan dapat menerapkan beberapa prinsip mengajar agar ia dapat melaksanakan tugasnya secara profesional, yaitu sebagai berikut.

1) Guru harus dapat membangkitkan perhatian perserta didik pada materi pelajaran yang diberikan serta dapat menggunakan berbagai media dan sumber belajar yang bervariasi.

2) Guru harus dapat membangkitkan minat peserta didik untuk aktif dalam bepikir serta mencari dan menemukan sendiri pengetahuan.

3) Guru harus dapat membuat urutan (sequence) dalam pemberian pelajaran dan penyesuaiannya dengan usia dan tahap tugas perkembangan peseta didik.

4) Guru perlu menghubungkan pelajaran yang akan diberikan dengan pengetahuan yang telah dimiliki peserta didik (kegiatan apersepsi), agar peserta didik menjadi mudah dalam memahami pelajaran yang diterimanya.

5) Sesuai dengan prinsip repetisi dalam proses pembelajaran, diharapkan guru dapat menjelaskan unit pelajaran secara berulang-ulang hingga tanggapan peserta didik menjadi jelas. 6) Guru wajib memperhatikan dan memikirkan korelasi atau hubungan antara mata pelajaran dan/atau praktik nyata dalam kehidupan sehari-hari.

7) Guru harus tetap menjaga konsentrasi belajar para peserta didik dengan cara memberikan kesempatan berupa pengalaman secara langsung, mengamati/meneliti, dan menyimpulkan pengetahuan yang didapatkanya.

8) Guru harus mengembangkan sikap peserta didik dalam membina hubungan sosial,baik dalam kelas maupun diluar kelas. 9) Guru harus menyelidiki dan mendalami perbedaan peserta secara individual agar dapat melayani siswa sesuai dengan perbedaannya tersebut.

Berdasarkan penjelasan di atas, maka tidak semua pekerjaan dapat dikatakan sebagai sebuah profesi, yang mana suatu pekerjaan dikatakan sebuah profesi iaalah pekerjaan yang harus memiliki keahlian khusus yang didapatkan melalui pendidikan.

Guru sebagai sebuah profesi di bidang pendidikan memiliki hak dan kewajiban yang menyangkut dunia pendidikan yang digeluti. Hak-hak guru merupakan apa-apa saja yang didapatkan oleh seseorang yang memiliki profesi guru, dan kewajiban guru adalah apa-apa saja yang harus dilaksanakan seorang guru dalam menjalankan profesinya. Hak dan

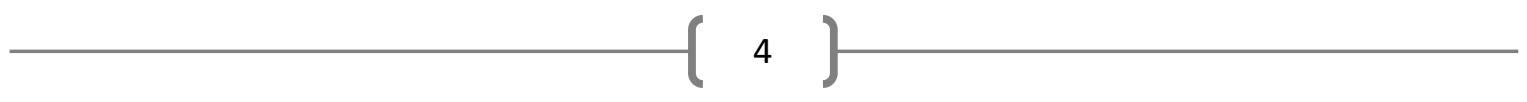


kewajiban guru ini dituangkan dalam UU No. 14 Tahun 2005 tentang guru dan dosen sehingga setiap guru mendapatkan perlindungan terhadap hak yang dimiliki dan kewajiban yang harus dilaksanakan.

Menurut Djaramah (2000) dalam Susanto (2020: 32) menjelaskan peranan seorang guru meliputi:

a. Korektor, artinya guru dapat membedakan mana nilai yang baik dan mana nilai yang buruk.

b. Inspirator, artinya guru dapat memberikan inspirasi yang baik untuk kemajuan belajar peserta didik

c. Informan, artinya guru harus memberikan informasi perkembangan ilmu pengetahuan dan teknologi, selain materi pelajaran yang telah diprogramkan dalam kurikulum.

d. Organisator, hal ini berkaitan dengan pengelolaan proses pembelajaran.

e. Motivator, disini guru berperan untuk mendorong peserta didik supaya semangat dan aktif dalam belajar.

f. Inisiator, artinya guru harus dapat menciptakan ide-ide untuk kemajuan dalam pembelajaran.

Dalam UU No. 14 Tahun 2005 tentang guru dan dosen pada bagian kedua mengenai hak dan kewajiban pada pasal 14, adapun hak yang dimiliki oleh seorang guru sebagai berikut:

a. Memperoleh penghasilan di atas kebutuhan hidup minimum dan jaminan kesejahteraan sosial. b. Mendapatkan promosi dan penghargaan sesuai dengan tugas dan prestasi kerja.

c. Memperoleh perlindungan dalam melaksanakan tugas dan hak atas kekayaan intelektual.

d. Memperoleh kesempatan untuk meningkatkan kompetensi.

e. Memperoleh dan memanfaatkan sarana dan prasarana pembelajaran untuk menunjang kelancaran tugas keprofesionalan.

f. Memiliki kebebasan dalam memberikan penilaian dan ikut menentukan kelulusan, penghargaan, dan atau sanksi kepada peserta didik sesuai dengan kaidah pendidikan, kode etik guru, dan peraturan perundang-undangan.

g. Memperoleh rasa aman dan jaminan keselamatan dalam melaksanakan tugas.

h. Memiliki kebebasan untuk berserikat dalam organisasi profesi. i. Memiliki kesempatan untuk berperan dalam penentuan kebijakan pendidikan. 
j. Memperoleh kesempatan untuk mengembangkan dan meningkatkan kualifikasi akademik dan kompetensi.

k. Memperoleh pelatihan dan pengembangan profesi dalam bidangnya.

Hak guru berarti suatu yang harus didaptkan olehnya setelah melakukan kewajibannya sebagai guru. Adapun hak yang dimiliki oleh seorang guru yang diatur dalam UU No. 14 Tahun 2005 di atas, kemudian dijabarkan lagi dalam Peraturan Pemerintah No. 74 Tahun 2008 yang dikutip dalam Susanto (2020:36):

a. Mengikuti uji kompetensi untuk memperoleh sertifikat pendidik bagi guru yang telah memiliki kualifikasi akademik S-1 atau D-IV

b. Memperoleh penghasilan di atas kebutuhan hidup minimum dan jaminan kesejahteraan sosial.

c. Mendapat tunjangan profesi, tunjangan fungsional dan subsidi tunjangan fungsional bagi guru yang memenuhi persyaratan sebagai berikut:

1) Memiliki satu atau lebih sertifikat pendidik yang telah diberi satu nomor registrasi guru oleh departemen memenuhi beban kerja sebagai guru;

2) Mengajar sebagai guru mata pelajaran dan/atau guru kelas pada satuan pendidikan yang sesuai dengan peruntukan sertifikat pendidik yang dimilikinya;

3) Terdaftar pada departemen sebagai guru tetap;

4) Berusia paling tinggi 60 (enam puluh) tahun; dan tidak terikat sebagai tenaga tetap pada instansi selain satuan pendidikan tempat bertugas.

d. Mendapat maslahat tambahan dalam bentuk:

1) Tunjangan pendidikan, asuransi pendidikan, beasiswa, atau penghargaan bagi guru;

2) Kemudahan memperoleh pendidikan bagi putra dan/atau putri guru, pelayanan kesehatan, atau bentuk kesejahteraan lain.

e. Mendapat penghargaan dalam bentuk tanda jasa, kenaikan pangkat prestasi kerja luar biasa baiknya, kenaikan jabatan, uang atau barang, piagam atau bentuk penghargaan lain.

f. Mendapat tambahan angka kredit setara untuk kenaikan pangkat setingkat lebih tinggi 1 (satu) kali bagi guru yang bertugas di daerah khusus.

g. Mendapatkan penghargaan bagi guru yang gugur dalam melaksanakan tugas pendidikan. 
h. Mendapatkan promosi sesuai dengan tugas dan prestasi kerja dalam bentuk kenaikan pangkat atau kenaikan jenjang jabatan fungsional.

i. Memberikan penilaian hasil belajar dan menentukan kelulusan kepada peserta didik

j. Memberikan penghargaan kepada peserta didik yang terkait dengan prestasi akademik dan atau prestasi non-akademik.

k. Memberikan sanksi kepada peserta didik yang melanggar aturan.

1. Mendapat perlindungan dalam melaksanakan tugas dalam bentuk rasa aman dan jaminan keselamatan

m. Mendapatkan perlindungan hukum dari tindak kekerasan, ancaman, perlakuan diskriminatif, intimidasi atau perlakuan tidak adil

n. Mendapatkan perlindungan profesi terhadap:

1) Pemutusan hubungan kerja yang tidak sesuai dengan ketentuan peraturan perundangundangan

2) Pemberian imbalan yang tidak wajar

3) Pembatasan dalam menyampaikan pandangan, pelecehan terhadap profesi, dan

4) Pembatasan atau pelarangan lain yang dapat menghambat guru dalam melaksanakan tugas.

o. Mendapatkan perlindungan keselamatan dan kesehatan kerja dari satuan pendidikan dan penyelenggara satuan pendidikan terhadap:

1) Resiko gangguan keamanan kerja,

2) Kecelakaan kerja

3) Kebakaran pada waktu kerja

4) Bencana alam

5) Kesehatan lingkungan kerja atau resiko lain.

p. Memperoleh perlindungan dalam melaksanakan hak atas kekayaan intelektual sesuai dengan ketentuan peraturan perundang-undangan.

q. Memperoleh akses memanfaatkan sarana dan prasarana pembelajaran

r. Berserikat dalam organisasi profesi guru.

s. Kesempatan untuk berperan dalam penentuan kebijakan pendidikan 
t. Kesempatan untuk mengembangkan dan meningkatkan kualifikasi akademik dan kompetensinya, serta untuk memperoleh pelatihan dan pengembangan profesi dalam bidangnya berhak memperoleh cuti studi.

Berdasarkan peraturan diatas, dapat kita ketahui bahwa hak guru dalam melaksanakan profesinya sudah sangat lengkap, berbagai hak tersebut seharusnya dapat menjadikan guru merasa aman dalam menjalankan tugasnya.

Kewajiban guru artinya segala sesuatu yang harus dilaksanakan oleh guru dalam melaksanakan tugasnya. Dalam melaksanakan tugas keprofesionalan dalam UU No. 14 tahun 2005 tentang guru dan dosen, pada pasal 20 maka kewajiban guru meliputi:

a. Merencanakan pembelajaran, melaksanakan proses pembelajaran yang bermutu, serta menilai dan mengevaluasi hasil pembelajaran.

b. Mengembangkan dan meningkatkan kualifikasi akademik dan kompetensi secara berkelanjutan sejalan dengan perkembangan ilmu pengetahuan, teknologi dan seni.

c. Bertindak objektif dan tidak diskriminatif atas dasar pertimbangan jenis kelamin, agama, suku, ras, dan kondisi fisik tertentu, atau latar belakang keluarga, dan status sosial ekonomi peserta didik dalam pembelajaran

d. Menjunjung tinggi peraturan perundang undangan, hukum dan kode etik guru, serta nilai nilai agama dan etika.

e. Memelihara dan memupuk persatuan dan kesatuan bangsa.

\section{GURU INDONESIA DAN TANTANGAN PROFESIONALISME}

Profesionalisme adalah suatu keahlian yang dimiliki seseorang dalam suatu bidang tertentu dan telah dapat memberikan sumbangan keprofesiannya (ilmu pengetahuan) kepada masyarakat yang membutuhkan. Guru yang professional adalah guru yang benar benar ahli dalam bidangnya dan mampu melaksanakan tugasnya dengan baik sekaligus memiliki kompetensi dan komitmen yang tinggi dalam menjalankan tugas dan tanggung jawabnya. (Muhson, 2004)

Susanto (2020) menjelaskan bahwa untuk menjadi guru profesional diperlukan berbagai kriteria. Kriteria tersebut berupa landasan keprofesionalan profesi guru dan kompetensi guru sebagaimana termuat dalam Undang-undang Guru dan Dosen serta 
Peraturan Mentri Pendidikan Nasional tentang kompetensi guru. Untuk dapat disebut guru profesional tidak hanya diperlukan kualifikasi pendidikan kesarjanaan bidang pendidikan, melainkan juga pemenuhan terhadap kompetensi profesional, kompetensi pedagogi, kompetensi sosial, dan kompetensi kepribadian. Keempat kompetensi ini merupakan paket utuh yang wajib dimiliki seorang guru sebagaimana diatur dalam peraturan perundangan yang disebutkan sebelumnya. Tidak terpenuhinya kompetensi tersebut akan berpengaruh pada pemenuhan kualitas layanan pendidikan. Berdasarkan penjelasan tersebut, menjadi guru bukanlah pekerjaan yang mudah. Guru bukan hanya menjalankan profesinya ketika dia berada di sekolah, melainkan juga di masyarakat. Ada seperangkat atribut yang melekat pada guru dalam pergaulan di sekolah maupun di masyarakat.

Profesionalisme guru di perlukan untuk memajukan pendidikan Indonesia karena keprofesionalan guru dalam mengajar berpengaruh untu mewujudkan tujuan pendidikan di Indonesia. Untuk menjadi guru yang profesional, seorang guru harus memiliki komptensi guru. Dalam hubungannya dengan tenaga profesional, kompetensi menunjuk pada performance yang berorintasi pada kualitas.

Kompetensi secara sederhana dapat diartikan sebagai paket kemampuat yang menunjukkan perpaduan antara pengetahuan, sikap, dan keterampilan dalam suatu bidang. Tiga aspek tersebut merupakan satu kesatuan yang membentuk kompetensi, sehingga seseorang dapat dikatakan kompeten apabila menunjukkan penguasaan ketiganya. (Susanto, 2020: 50)

Kompetensi guru meliputi kompetensi pedagogik, kompetensi kepribadian, kompetensi sosial, dan kompetensi profesional yang diperoleh melalui pendidikan profesi. Kompetensi pedagogik menunjuk pada kemampuan mengelola pembelajaran peserta didik. Kompetensi kepribadian menunjuk pada kemampuan kepribadian yang mantap, berakhlak mulia, arif, dan berwibawa serta menjadi teladan peserta didik. Kompetensi profesional menunjuk pada kemampuan penguasaan materi pelajaran secara luas dan mendalam. Kompetensi sosial menunjuk kemampuan guru untuk berkomunikasi dan berinteraksi secara efektif dan efisien dengan peserta didik, sesama guru, orangtua/wali peserta didik, dan masyarakat sekitar. 


\section{SIMPULAN}

Profesi guru merupakan profesi yang sangat penting dan berkontribusi langsung terhadap kemajuan suatu bangsa. Sebagai suatu profesi, guru idealnya memiliki syarat-syarat khusus untuk dapat dijalani oleh seseorang. Diperlukan kompetensi khusus untuk menjadi seorang guru. Untuk dapat disebut guru profesional tidak hanya diperlukan kualifikasi pendidikan kesarjanaan bidang pendidikan, melainkan juga pemenuhan terhadap kompetensi profesional, kompetensi pedagogi, kompetensi sosial, dan kompetensi kepribadian.

\section{REFERENSI}

Efendi, I., Prawitasari, M., \& Susanto, H. (2021). Implementasi Penilaian Pembelajaran Pada Kurikulum 2013 Mata Pelajaran Sejarah. Prabayaksa: Journal of History Education, 1(1), 21-25.

Susanto, H. (2020). Profesi Keguruan. Banjarmasin: FKIP Universitas Lambung Mangkurat.

Susanto, H., \& Akmal, H. (2018). Efektivitas Penggunaan Aplikasi Pembelajaran Berbasis Mobile Smartphone Sebagai Media Pengenalan Sejarah Lokal Masa Revolusi Fisik Di Kalimantan Selatan Pada Siswa Sekolah Menengah Atas. HISTORIA: Jurnal Program Studi Pendidikan Sejarah, 6(2), 197-206.

Susanto, H., Irmawati, I., Akmal, H., \& Abbas, E. W. (2021). Media Film Dokumenter Masuknya Islam Ke Nusantara dan Pengaruhnya Terhadap Keterampilan Berpikir Kritis Siswa. HISTORIA: Jurnal Program Studi Pendidikan Sejarah, 9(1).

Syaharuddin, S., \& Susanto, H. (2019). Sejarah Pendidikan Indonesia (Era Pra Kolonialisme Nusantara sampai Reformasi). Banjarmasin: FKIP Universitas Lambung Mangkurat.

Muhson, A. (2004). Meningkatkan Profesionalisme Guru: Sebuah Harapan. Jurnal Ekonomi dan Pendidikan, 1(2). 
Seri Publikasi Pembelajaran

Vol 1 No 2(2021): Profesi Keguruan

Nurjan, S. (2015). PROFESI KEGURUAN (Konsep dan Aplikasi). 